\title{
Wetlands In Northern Plains Prairies: Offer Societal Values Too
}

\section{Unlike wildlife habitat and livestock forage, societal services provided by prairie wetlands are not easily observed, measured or valued.}

\author{
By Donald R. Kirby, Kelly D. Krabbenhoft, \\ Kevin K. Sedivec and Edward S. DeKeyser
}

$\mathrm{W}$ etlands provide services to society in addition to the obvious services such as wildlife habitat and livestock forage. Most northern prairie wetlands remaining today lie in watersheds dominated by agriculture. This may have been the primary reason for Adamus and Stockwell (1983) to list wetland sediment trapping and nutrient removal as the greatest positive impact on water quality and a primary reason that wetlands have been legally protected by states and the nation. At the ecosystem level, wetlands have value to the public of which maintenance of water quality, groundwater recharge, and flood attenuation will be discussed here.

\section{Maintenance Of Water Quality}

Wetlands play a critical role in the maintenance of water quality by removing materials entering a wetland via water movement such as suspended solids, nutrients, metals, pathogens, and biological oxygen demand. There are two major methods in which wetlands improve water quality:

1) they adsorb nutrients or tie up metals and incorporate them into the soil

2) the vegetation incorporates nutrients and metals into their tissues and release the materials into the soil as dead organic matter
Sediment, organic matter, and other suspended solids arrive in a wetland via runoff in the form of particulate litterfall, or in water flowing from other water sources. Suspended sediments can be detrimental to wetlands by inhibiting light penetration, decreasing dissolved oxygen, and toxic substances, as well as nutrients, entering into wetlands. Wetlands assist in settling suspended solids by reducing water movement and catching suspended solids by stands of emergent vegetation.

Nitrogen and phosphorus are two nutrients that, in excess, are considered pollutants in wetland ecosystems. Wetlands incorporate nitrogen through uptake by plants, microorganisms, or sedimentation. Nitrogen is also removed and discharged into the atmosphere via release of $\mathrm{N}_{2}$ gas. Phosphorus is mainly immobilized by plant uptake and decomposition into wetland sediments.

Metals are mainly tied up in wetlands by adsorption to sediments or to clay and organic compounds found in the soil, but may also precipitate as oxides, phosphates, or other salts. Plants may also incorporate metals into tissue and eventually release dead litter into the soil or rerelease the metals back into the water. Pesticides generally are adsorbed or incorporated in the same fashion as metals.
Pathogens, such as bacteria and viruses, usually are concerns in wetlands receiving sewage wastewater. Wetlands can remove pathogens, such as bacteria, by confining them until they die naturally. For example, protozoa may feed on bacteria, and excretions from some plant species can also kill bacteria. Wetlands also have the capacity to trap a virus by incorporating it into the soil.

Wetlands tend to remove the biological oxygen demand needed for the microbial decomposition of organic matter and oxidation of inorganic material. If the biological oxygen demand is high in a wetland, the amount of dissolved oxygen in the water could become low and decomposition by microorganisms located in the wetland is lowered or ceases. Overall, the filtering ability of wetlands aids the improvement of groundwater, river and other water resource quality in the Northern Great Plains.

\section{Groundwater Recharge}

The hydrologic functioning of prairie pothole wetlands have not been studied extensively. Most Prairie Pothole Region wetlands are small sized, isolated and located within topographic depressions in glacial till. Water permanence, chemistry and biological characteristics of prairie wetlands are highly 
variable in time and space indicating that their hydrologic functions are probably complex as well.

However, their hydrologic functions have been of interest and at the center of conflict between agricultural producers and environmentalists. Some hydrologists tend to agree that some wetlands do recharge the groundwater system, but many do not.

In the Prairie Pothole Region, wetlands typically form large complexes of recharge and discharge patterns connected by shallow groundwater flow systems as shown in Figure 1 (Richardson and Vepraskas 2001). Ephemeral, temporary and seasonal class wetlands (short term flooded) are typically higher on the landscape and are classified by hydrologists as recharge wetlands. They typically act to collect surface runoff of water and, having a water level higher than the water table, recharge shallow aquifers. Recharge wetlands normally have soils with high infiltration and percolation rates.

Larger wetlands classified as semipermanent and permanent wetlands (seasonally to permanently flooded) are generally lower on landscapes and are classified by hydrologists as flow-through and discharge wet- lands. At least part, if not most, of the water these larger wetlands receive is through groundwater flow from shallow aquifers created by recharge wetlands positioned higher on the landscape.

Soils of semipermanent and permanent wetlands are typically impermeable and most hydrologists agree that they perform little to no recharge function. Through evaporative discharge, semipermanent and permanent wetlands act to discharge water through evapotranspiration and other surface outflows and, thereby, lower the groundwater level of the surrounding region. However, these types of wetlands can be adversely affected by large-scale domestic or industrial groundwater removals.

Large-scale well withdrawals of water near discharge wetlands may cause a reversal of groundwater flow such that the affected wetland becomes a recharge wetland (Richardson and Vepraskas 2001). This alteration of the groundwater flow could potentially have adverse affects on the quality and quantity of groundwater supply as well as the integrity of the wetland itself.

As with many other wetland functions, the role prairie wetlands play in groundwater systems is still, for the most part, unclear. More work is needed to fully understand the "service" prairie wetlands may perform in groundwater recharge.

\section{Flood Attenuation}

The role prairie wetlands play in flood attenuation or protection is a hotly debated issue. This issue usually arises following a flood event that causes losses in human life and/or damages to private property. Therefore, floods and the role wetlands play during these events become an emotional issue rather than an environmental issue. Furthermore, floods occur erratically in time and space making "scientific" study difficult at best.

Despite the debates, floods cause billions of dollars in damages to homes, properties and crops each decade. Policymakers, agencies, cities, researchers and the public are constantly attempting to discover means to reduce the number and severity of floods. Wetlands, transitional areas between terrestrial and aquatic ecosystems, are often viewed as areas needing legislation or restoration for mitigating flood magnitudes and recurrences.

Wetlands, in some circumstances, influence regional water flow

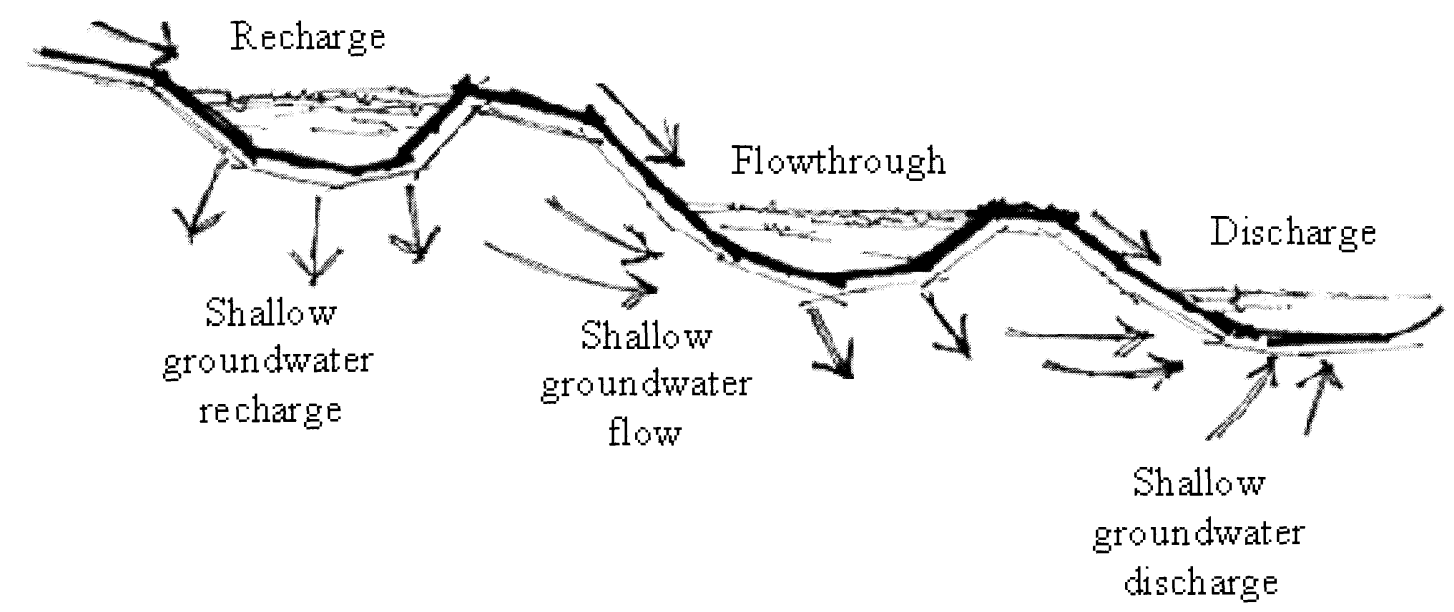

Figure 1. Generalized surface and subsurface water flow in a glaciated prairie landscape containing recharge, flowthrough and discharge wetlands. 
regimes by intercepting and storing at least some storm waters, thus reducing flood peaks and creating longer time periods of discharge. Hubbard and Linder (1986) concluded, in the Altamont Moraine of northeastern South Dakota, that smaller prairie wetlands (potholes) lowered flood discharges. They calculated that 213 small wetlands over a 1600 acre area stored an estimated 160 acre-feet (160 acres of water to a depth of one foot) of water. By extrapolation, they reasoned that small wetlands in this region could hold large quantities of storm runoff and lower flood discharge volumes.

A modeling study by the U.S. Army Corps of Engineers (1994) in the Mississippi River Basin suggested that, by restoring upland wetlands that had been previously drained, flood peaks could be reduced by 10 to $23 \%$ in watersheds with larger, deeper wetlands. The model showed a 5 to $9 \%$ reduction in flood peaks from watersheds containing smaller, shallower wetlands. The model indicated that wetlands were most effective at mitigating flood damage during typical 25-year or less storm events.

Novitzki (1985) reported that a watershed comprised of 4 to $5 \%$ wetlands would have a $50 \%$ reduction in peak flood period compared to a watershed lacking wetlands. Demissie and Kahn (1983) agreed with Novitzki by concluding that a 50 -year flood event on the Kankakee River in Illinois was $50 \%$ less than a similar 50-year flood event on the Iroquois River in Indiana (where wetlands had been drained) because of wetlands being present in the Kankakee River watershed despite the two watersheds being equal in size.

Wetland location within a watershed in relation to their flood attenu-

one that exceeds a gauge level of 40 feet. Despite floods in the early 1800's being poorly documented, numerous severe floods were noted when the environment of the Red River Valley was essentially unaltered. Official flood level records have been main-

ation properties is also debated. Some have suggested that small wetlands remaining in the upper basin of watersheds were more effective for flood control than larger, downstream wetlands. In contrast, others have claimed that the further downstream larger wetlands were located, the more value the wetlands would play in reducing flood peaks.

Knight (1993), in a review of these and other studies, summarized that small wetlands naturally occurring in the upper reaches of watersheds were best for attenuating normal, high frequency downstream floods, while natural downstream wetlands were best at controlling larger than normal, low frequency flood events. Shultz (1999) stated that due to the complexity and interactions of rainfall, wetland volume, and prior water conditions, that it is difficult if not impossible to generalize on the effects prairie wetlands have in flood attenuation. Arguments arise that if wetlands are already full of water, as is often the case during wet periods and before storm events, then little to no storage is available to retain runoff. Hence, prairie wetlands are not very effective for flood protection or prevention.

Bluemle (1997) researched floods in the Red River Valley at Grand Forks, North Dakota, and reported from eyewitness accounts that the Red River experienced at least six extremely severe floods ( $>50$ feet) between 1800 and 1855. A severe flood in Grand Forks is defined as tained from 1882 to present and during this time severe floods have occurred every 4 to 5 years. Bluemle concluded that severe floods in the Red River Valley occur naturally during cycles of increased rainfall and snowmelt and were not "caused" by wetland drainage.

In summary, proponents of wetlands as flood attenuation features argue that it seems reasonable that prairie wetlands catch and retain overland water flow in watersheds, thereby decreasing peak flows downstream. The opposite argument is that it seems logical when wetlands are already full of water, as is the case in a flood year, then their potential for water storage is not available during a flood event, hence they play little to no part in regulation of downstream peak flows. As was previously stated, little "scientific" data is available supporting either side of the debate. Further research will be needed to answer the question, "What role do prairie wetlands play in flood attenuation?"

Unlike wildlife habitat and livestock forage, societal values of wetlands are not easily observed, measured or valued. Despite this, numerous acts and laws have been passed by congress and states throughout the 1980's and 1990's to protect these ecosystems. There are also numerous incentives for land owners to preserve wetlands, including drainage disincentives and ecological restoration incentives. However, the ecological functions wetlands play in improving our environment are 
not well understood and are in need of study.

Authors are professor, Animal and Range Sciences Department NDSU; environmental specialist, Coteau Properties Company, Beulah, ND 58523; state extension rangeland specialist, and rangeland specialist, Animal and Range Sciences Department, North Dakota State University, Fargo, ND 58105.

\section{References}

Adamus, P.R. and L.T. Stockwell. 1983. A method for wetland functional assessment. I. Critical review and evaluation concepts. U.S. Dept. Transportation, Federal Highway Admin. Rep. No. FHWA-IP-82-23.
Bluemle, J.P. 1997. Factors affecting flooding in the Red River Valley. Proc. N.D. Acad. Sci. 51:17-20.

Demissie, M. and A. Kahn. 1993. Influence of wetlands on streamflow in Illinois. Rept. 561. Illinois State Water Survey, Hydrology Division, Champaign.

Hubbard, D.E. and R.L. Linder. 1986. Spring runoff retention in prairie pothole wetlands. J. Soil and Water Conserv. 41:122-125.

Knight, R.I. 1993. Ancillary benefits and potential problems with the use of wetlands for nonpoint source pollution control. p. 131-150 in R.K. Olsen, (ed.) Created and natural wetlands for controlling nonpoint source pollution. Off. Wetlands, Oceans, and Watersheds, USEPA, Wash. D.C.

Novitzki, R.P. 1985. The effects of lakes and wetlands on flood flows and base flows in selected northern and eastern states. in H.A. Gromman, et al. (eds.) Proc. Wetlands Conf. of the Chesapeake. Environ. Law Institute, Wash., D.C.

Richardson, J.L. and M.J. Vepraskas. 2001. Wetland Soils, Genesis, Hydrology, Landscapes, and Classification. Lewis Publishers, New York. 417 pp.

Shultz, S.D. 1999. The feasibility of wetland restoration to reduce flooding in the Red River Valley: A case study of the Maple (ND) and Wild Rice (MN) watersheds. Agri. Econ. Rep. No. 432, North Dakota State Univ., Fargo. 59 pp.

U.S. Army Corps of Engineers. 1994. Sharing the challenge: Floodplain management into the $21^{\text {st }}$ century. Report of the Interagency Floodplain Manage. Rev. Comm., Wash., D.C.

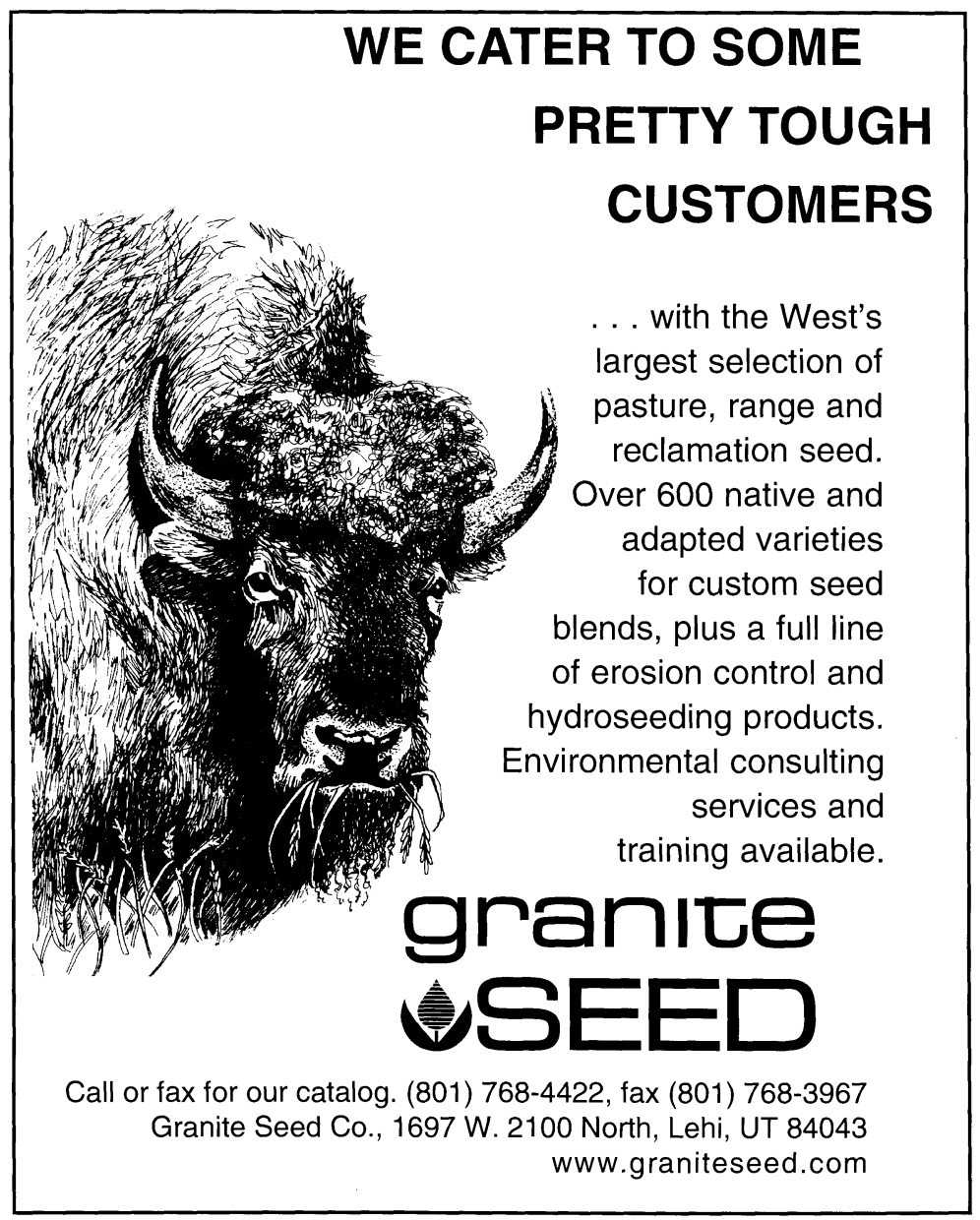

